\title{
GENEOLOGI HERMENEUTIKA HUKUM ISLAM (Fikih Kontekstual ‘Umar bin Al-Khațțāb)
}

\author{
Muhammad Anshori \\ UIN Sunan Kalijaga Yogyakarta
}

Email: anshori92@gmail.com/087839234275

\begin{abstract}
This paper analyzes the thought or contextual interpretation of 'Umar bin al-Khattāb which is closely related to hermeneutics. In the Islamic thought tradition, hermeneutics as a method of interpreting the holy book has been done in the early days of the emergence of Islam. If traced further, the Prophet Muhammad himself had done it. However, the term hermeneutics that has developed in the Western world feels foreign to Muslims. One of the classical Islamic thinkers who has progressive thoughts and transcends his time in understanding or interpreting the Al-Qur' an is 'Umar bin AlKhattāb. His thought is the genealogy of contextual interpretation developed by modern-contemporary thinkers. In term of the periodicity of Islamic history, 'Umar bin Al-Khattäb's idea can be categorized as classical hermeneutics because it emerged in the early days of Islam, but it was very contextual and progressive. Therefore, it is not surprising to say that he was one of the early hermeneutics of Muslims.
\end{abstract}

Keywords: Genealogy, Hermeneutics, Classical period, 'Umar Ibn al-Khatțāb.

\begin{abstract}
Abstrak
Tulisan ini menganalisis tentang pemikiran atau penafsiran kontekstual 'Umar bin al-Khaț̣āb yang memiliki kaitan erat dengan hermeneutika. Dalam tradisi pemikiran Islam, hermeneutika sebagai metode tafsir kitab suci sudah dilakukan pada masa-masa awal kemunculan Islam. Jika dilacak lebih jauh, Nabi Muhammad sendiri telah melakukannya. Namun, karena istilah hermeneutika yang berkembang di dunia Barat memang terasa asing di kalangan umat Islam. Salah satu tokoh pemikir Islam klasik yang memiliki pemikiran progresif dan melampaui zamannya dalam memahami atau menafsirkan Al-Qur'an adalah 'Umar. Inilah geneologi tafsir kontekstual yang dikembangkan oleh pemikir-pemikir modern-kontemporer. Dari segi periodesasi sejarah Islam, pemikiran 'Umar bisa dikategorikan sebagai hermeneutika klasik karena memang terjadi pada masa-masa awal Islam.
\end{abstract}


Pemikiran 'Umar sangat kontekstual dan progresif. Karena itu, tidak heran jika dikatakan bahwa ia termasuk hermeneut awal umat Islam.

Kata kunci: : Geneologi, Hermeneutika, Klasik, dan ‘Umar bin al-Khațāō.

\section{A. PENDAHULUAN}

Bagi sebagian kalangan, hermeneutika sebagai sebuah disiplin keilmuan masih diperselisihkan atau diperdebatkan karena dianggap sebagai produk Barat-Kristen. Kalangan yang menolak hermeneutika lebih melihat "bungkus" daripada "isi", padahal hermeneutika merupakan nama lain dari fiqh al-ta'wīl yang telah lama dikenal dalam tradisi pemikiran Islam. Bahkan hukum Islam (Islamic Law) atau yang disebut dengan fikih (Islamic Jurisprudence) merupakan bagian dari tradisi hermeneutika. Hermeneutika sebagai metode penafsiran kitab suci atau pemahaman hukum Islam telah ada sejak masa Nabi Muhammad, dan dipraktikkan oleh beberapa sahabat. Salah satu fikih kontekstual adalah yang dilakukan oleh 'Umar bin al-Khațtāb (w. 23 H/644 M) sebagai bentuk implementasi dari hermeneutika Islam klasik.' Pemikiran atau ijtihad fikih 'Umar telah melampaui masanya sehingga perlu mendapat perhatian dari kalangan sarjana muslim (insiders) dan non-muslim (outsiders).

Hermeneutika dalam arti metode penafsiran serta pemahaman kitab suci atau teks lainnya cukup banyak dilakukan oleh sarjana-sarjana

1 Mengapa saya memilih Hermeneutika Klasik dalam tradisi Islam dengan menganalisis pemikiran 'Umar bin Al-Khațāa (w. 23 H/644 M)? Ada beberapa alasan yang membuat saya ingin mengkaji hal ini: Pertama, jika hermeneutika diartikan sebagai metode menafsirkan atau memahami kitab suci, sebenarnya dalam Islam sudah ada sejak masa Nabi Muhammad dan sahabat-sahabatnya. Jika merujuk pada unsur hermeneutika, pengarang (author), teks (text), dan pembaca (reader), maka hal tersebut sering dilakukan oleh banyak kalangan intelektual, bukan hanya dari luar Islam, tetapi juga dari kalangan Islam sendiri. Kedua, 'Umar bin al-Khaț̣̄āb dikenal sebagai sahabat yang sangat progresif dan inovatif dalam memahami teks-teks keagamaan, terutama sekali al-Qur'an dan hadis. Jika menggunakan istilah Abdullah Saeed, maka 'Umar termasuk kategori penafsir kontekstualis. Kontekstualisasi inilah yang menjadi ciri umum aplikasi hermeneutika. Ketiga, untuk membuktikan bahwa tradisi hermeneutika tidak hanya menjadi dominasi pemikiran-pemikir Barat-Kristen, tetapi dalam Islam juga sudah ada tradisi hermeneutika. 
muslim. Hasil produk pemikiran ini telah melahirkan dan mengembangkan hukum Islam atau fikih. Hal ini tidak mengherankan jika banyak pemikirpemikir dunia Islam yang dianggap sebagai hermeneut (mufassir) dalam arti memberikan metode dan pendekatan dalam memahami teks-teks keagamaan, seperti Fazlur Rahman (1919-1988), Nașr Ḥāmid Abū Zaid (w. 2010), Muhammad Syaḥūr (1928-sekarang), Muhammad Arkoun (19282010), Muhammad Abied al-Jabiri (1935-2010), Mahmud Muhammad Thaha (1909-1985), Abdullahi Ahmed An-Naim (1946-?), Abdul Karim Soroush (1945-?), Hassan Hanafi (1935-2010), Khaled Abou el-Fadl (1963sekarang), Abdullah Saeed (1960-sekarang), Yudian Wahyudi (1960sekarang), M. Amin Abdullah (1953-sekarang), Komarudin Hidayat (1953sekarang), Nur Kholis Setiawan (1970-sekarang), M. Quraish Shihab (1944sekarang), Nasaruddin Umar (1959-sekarang), Sahiron Syamsuddin (1968sekarang), Yusuf Rahman (1967-sekarang), Fahruddin Faiz, Aksin Wijaya (1974-sekarang), Abdul Mustaqim (1972-sekarang), dan lain-lain. Ini menunjukkan bahwa hermeneutika tidak hanya digunakan untuk menafsirkan Bibel meskipun dari segi sejarah lahir dari dunia Kristen. Seiring dengan berjalannya waktu, hermeneutika menjadi metode sekaligus pendekatan dalam memahami teks-teks keagamaan.

Dalam tulisan ini, penulis akan mencoba untuk menganalisis metode pemahaman atau penafsiran hukum Islam salah satu tokoh klasik yaitu 'Umar bin al-Khațāâ (w. 23 H/644 M). Ia dikenal sebagai sahabat yang sangat kreatif dan inovatif dalam berijtihad, meskipun secara zahir melanggar teks-teks keagamaan. Namun jika dianalisis secara mendalam sebenarnya tidak demikian, ada beberapa alasan yang membuat 'Umar melakukan penafsiran "liberal". Sebelum membahas biografi dan pemikiran fikih kontekstual 'Umar, terlebih dahulu akan dijelaskan secara singkat tentang hermeneutika. 


\section{B. SEKILAS TENTANG HERMENEUTIKA}

Dalam kajian teks-teks keagamaan kontemporer, salah satu istilah yang bisa disejajarkan dengan tafsir atau syarh adalah hermeneutika. Dalam tradisi Islam, problem penggunaan hermeneutika sebenarnya sudah diselesaikan oleh Hassan Hanafi dalam disertasinya; Les methodes d'exegese: essai sur la science des fondaments de la comprehension "Ilm Ușūl al-Figh" (Metode Tafsir: Kajian tentang Ilmu-ilmu Sendi-sendi Pemahaman, yaitu "Ushul Fikih"). Buku ini merupakan disertasi doktor Hanafi di Universitas Sorbonne tahun 1965.2 Kata hermeneutika berasal dari bahasa Yunani yaitu hermeneuin, yang dalam bahasa Inggris disebut hermeneutic. Kata ini sering diterjemahkan dengan to interpret yang berarti menginterpretasikan, menafsirkan dan menerjemahkan. Dalam studi keislaman, hermeneutik sudah lama dikenal dalam kajian tafsir dan lainnya. Padanan kata yang dianggap sepadan dengan hermeneutik adalah tafsìr, ta'wīl', syarh dan bayān. Tradisi tersebut sudah lama menjadi bagian dari perkembangan ilmu keislaman dalam kajian tafsir, fiqih, kalam, ${ }^{3}$ tasawuf, dan tentu juga hadis. Jika hermeneutika dipahami dalam pengertian metode, maka ia berisikan pembahasan teoritis tentang the conditions of possibility sebuah penafsiran. Tentu menyangkut hal-hal yang dibutuhkan atau prosedur yang harus dipenuhi untuk menghindari pemahaman yang keliru (misunderstanding/misinterpretation) terhadap teks. ${ }^{4}$

Menurut Zygmunt Bauman (1925-2017), hermeneutika berasal dari bahasa Yunani "hermeneutikos" yang berkaitan dengan upaya menjelaskan atau menelusuri pesan dan pengertian dasar dari sebuah ucapan atau

2 Yudian Wahyudi, kata pengantar dalam buku Hassan Hanafi, Hermeneutika Al-Qur'an?, trj. Yudian Wahyudi dan Hamdiah Latif (Yogyakarta: Pesantren Nawasea Press, cet-II, 2009 M), hlm. v.

${ }^{3}$ Muzairi, "Hermeneutika dalam Pemikiran Islam", dalam Sahiron Syamsuddin, dkk, Hermeneutika Al-Qur'an Mazhab Yogya (Yogyakarta: Penerbit Islamika, cet-I, 2003 M), hlm. 54.

${ }^{4}$ Ilham B. Saenong, Hermeneutika Pembebasan: Metodologi Tafsir al-Qur'an Menurut Hassan Hanafi (Bandung: Mizan Media Utama, cet-I, 2002), hlm. 25. 
tulisan yang masih tidak jelas, kabur, remang-remang, dan penuh kontradiksi. Hal ini bisa menimbulkan keraguan dan kebingungan bagi para pendengar atau pembacanya. ${ }^{5}$ Meskipun berbeda dengan definisi di atas tetapi makna dan tujuannya sama yaitu menjelaskan makna teks yang masih belum jelas. Jika hermeneutika diartikan sebagai penjelasan tentang maksud firman-firman Tuhan, maka tidaklah keliru jika dikatakan bahwa sebenarnya hal itu telah dikenal oleh ulama Islam jauh sebelum munculnya hermeneutika di Barat. Ini paling tidak berarti sebagian dari bahasan hermeneutika yang muncul dewasa ini telah dikenal oleh ulama-ulama Islam.

Istilah hermeneutika dapat ditemukan dalam literatur peninggalan Yunani kuno, seperti Organon karya Aristoteles yang di dalamnya terdapat istilah terkenal peri hermeneias (tentang penafsiran). Istilah ini digunakan dengan bentuk nominal dalam Epos Oedipus at Colunus, yang beberapa kali muncul dalam tulisan Plato. Selain itu, dalam karya-karya penulis kuno seperti Xenophon, Plutarch, Euripides, Epicurus, Lucretius, dan Longinus. ${ }^{6}$ Menghubungkan kata hermeneutik dengan kata Hermes -secara sekilasmenunjukkan adanya tiga unsur dalam aktivitas penafsiran, yaitu (1). Tanda, pesan, atau teks yang menjadi sumber atau bahan dalam penafsiran yang dihubungkan dengan pesan yang dibawa oleh Hermes. (2). Perantara (mediator) atau penafsir (interpreter), dan (3). Penyampaian pesan itu oleh sang perantara agar bisa dipahami dan sampai kepada yang menerima. ${ }^{7}$

\footnotetext{
${ }^{5}$ Komaruddin Hidayat, Menafsirkan Kehendak Tuhan (Jakarta: Teraju, cet-II, 2004), hlm. 138.

${ }^{6}$ M. Nasaruddin Umar, Menimbang Hermeneutika sebagai Manhaj Tafsir, dalam Jurnal Studi Al-Qur'an, Vol-I, No, 1, Januari, 2006 (Ciputat: Pusat Studi Al-Qur'an), hlm. 42-43.

7 Fakhruddin Faiz, Hermeneutika Qur'ani: Antara Text, Konteks, dan Kontekstualisasi (Yogyakarta: Qalam, 2002), hlm. 21. Ini dikutip juga oleh Umiarso, "Hassan Hanafi: Pendekatan Hermeneutik dalam Menghidupkan Tuhan", dalam Hasan Baharun dan Akmal Mundir, dkk, Metodologi Studi Islam: Percikan Pemikiran Tokoh dalam Membumikan Agama (Yogyakarta: Ar-Ruzz Media, cet-III, 2014), hlm. 195. Buku ini menyajikan enam tokoh pemikir, yaitu (a). Hidayat Nataatmadja, lahir di Banten 15 September 1932 dan wafat hari Selasa 13 Januari 2009 di Bogor. (2). Mehdi Golshani, Ian G. Barbour, Ismail Raji Al-Faruqi, Armahedi Mazhar, Hassan Hanafi, Mohammed Arkoun, Mehdi Ha'iri Yazdi, dan Abdul Rasyid Motten.
} 
Dilihat dari cara kerjanya, hermeneutika merupakan teori tentang metode pemahaman dalam menafsirkan teks. Jadi gagasan kuncinya adalah realisasi diskursus sebagai teks. Ben Vedder membedakan empat istilah yang terkait dengan hermeneutika, pertama, hermeneuse; penjelasan atau interpretasi sebuah teks, karya seni atau perilaku seseorang. Kedua, hermeneutik, membicarakan tentang aturan, metode atau langkah-langkah dalam penafsiran. Ketiga, philosophische, membahas tentang kondisi-kondisi kemungkinan dalam memahami dan menafsirkan sebuah teks, simbol atau prilaku. Keempat, hermeneustische philosophie, merupakan bagian dari pemikiran filsafat yang coba menjawab problem kehidupan manusia dengan cara menafsirkan apa yang diterima oleh manusia dari sejarah dan tradisi. ${ }^{8}$

Sebagian sarjana yang bergelut dalam bidang hermeneutika, ada yang menitikberatkan pengertian kata tersebut kepada Hermes. Menurut Gerhard Ebeling (1912-2001), Hermes merupakan kiasan untuk tiga tugas utama hermeneutika modern. Pertama, mengungkapkan sesuatu yang tadinya masih berada dalam pikiran melalui kata-kata (utterance, speaking) sebagai medium penyampaian. Kedua, menjelaskan secara rasional (interpretation, explanation) sesuatu yang sebelumnya masih samar-samar sehingga maksud atau maknanya dapat dimengerti. Ketiga, menerjemahkan (translating) suatu bahasa yang asing ke dalam bahasa yang lebih dipahami atau dikuasai. ${ }^{9}$ Definisi ini hampir senada dengan definisi Zygmunt Bauman (1925-2017) di atas. Richard E. Palmer mengemukakan bahwa ada enam titik tekan kajian hermeneutika yaitu:

Pertama, hermeneutika sebagai teori penafsiran kitab suci. Hermeneutika dalam bentuk ini terdapat dalam tradisi gereka di mana

8 Dikutip dari Sahiron Syamsuddin, Hermeneutika dan Pengembangan Ulumul Qur'an (Yogyakarta: Pesantren Nawesea Press, cet-I, 2009 M), hlm. 7-10.

9 M. Nasaruddin Umar, Menimbang Hermeneutika.....hlm. 43. Nasaruddin mengutip pendapat Gerhard Ebeling dari Jean Grondin, Introduction to Philosophical Hermeneutics. 
masyarakat Eropa mendiskusikan otentitas Bibel untuk mendapatkan kejelasan maknanya. Hermeneutika dalam bentuk ini identik dengan prinsip interpretasi. Kenyataan ini bisa dijumpai sampai sekarang, terutama jika dihubungkan dengan penafsiran kitab suci (exegesis of scripture). Bentuk hermeneutika seperti ini dikaji oleh Johann Conrad Dannhauer (1603-1666). Kajian semacam ini memiliki berbagai macam bentuk dan melahirkan berbagai corak pemikiran, seperti yang dilakukan Martin Luther (1483-1546) yang memberikan interpretasi dalam Bibel melalui mistik, dogmatik, humanis, dan lain sebagainya. ${ }^{10}$

Kedua, hermeneutika sebagai sebuah metode filologi. Perjalanan filologi klasik pada abad 18 mempunyai pengaruh terhadap studi Bibel, kenyataan ini menimbulkan metode kritik sejarah dalam teologi. Kajian ini dimulai oleh Ernesti pada tahun 1761 M. sampai akhirnya corak ini dianggap sebagai penafsiran sekuler oleh pihak gereja. Namun, sejak munculnya abad pencerahan di Eropa sampai sekarang, metode Bibel tidak dapat dipisahkan dengan metode research dalam filologi. Kehadiran bentuk ini mulai tampak pada abad 19 yang sering didiskusikan oleh filolog, seperti Schleirmarcher (1768-1834),11 F. August Wolf (1759-1824), dan Friedrich Ast (1778-1841). Dalam hal ini mereka memberi porsi yang sama terhadap tafsir kitab suci dan kajian teks atau pemikiran lainnya. ${ }^{12}$

Ketiga, hermeneutika sebagai ilmu pemahaman linguistik (science of linguistic understanding). Scheleirmacher membedakan hermeneutik sebagai science (ilmu) dan hermeneutika sebagai seni memahami (art of understanding). Bentuk memahami dalam hermeneutika merupakan arti secara umum dalam keilmuan hermeneutik dan hal ini masih digunakan

${ }^{10}$ Lihat penjelasan ini dalam Muzairi, Hermeneutika dalam Pemikiran Islam, dalam Sahiron Syamsuddin, dkk, Hermeneutika Al-Qur'an Mazhab Yogya, hlm. 54-55.

11 Friedrich Daniel Ernst Schleiermacher merupakan seorang teolog dan filsuf Jerman. Dia lahir tanggal 21 November 1768 di Wrocław, Polandia, dan meninggal tanggal 12 Februari 1834 di Berlin, Jerman.

12 Muzairi, Hermeneutika dalam Pemikiran Islam, hlm. 55. 
sampai saat ini. Oleh karena itu dari perspektif historis, hermeneutika dianggap sebagai "pahlawan" dalam penafsiran Bibel serta filologi tradisional. Dengan adanya filologi merupakan tanda adanya pemahaman linguistik terhadap teks. ${ }^{13}$

Keempat, hermeneutika sebagai fondasi ilmu kemanusiaan. Kerangka hermeneutik dalam bentuk ini dimulai oleh Wilhelm Dilthey (1833-1911). Ia berusaha membawa hermeneutika dalam menafsirkan ilmu kemanusiaan, seperti menginterpretasikan ekspresi kehidupan manusia. Wilhelm Dilthey (1833-1911) memberikan kritik terhadap Immanuel Kant (1724-1804), terutama dalam pure reasonnya. Dalam perkembangan pemikiran selanjutnya, Dilthey berusaha menginterpretasikan psikologi dalam memahami dan interpretasi. ${ }^{14}$

Kelima, hermeneutika sebagai fenomena das sein dan pemahaman eksistensial. Tokoh utama corak ini adalah Martin Heidegger (1889-1976) yang berangkat dari filsafat eksistensialis yang dipengaruhi oleh gurunya, Edmund Husserl (1859-1938). Dalam perkembangannya, hermeneutika filosofis ini dikembangkan oleh Hans-George Gadamer (1900-2002) yang memberikan perhatian lebih terhadap hermeneutika dalam kajian filsafat. Ia tidak percaya dengan adanya metode tertentu untuk mendapat pemahaman yang baik dalam interpretasi teks. ${ }^{15}$ Keenam, hermeneutika sebagai sistem penafsiran. Kajian ini dikemukan oleh Paul Ricouer (19132005), salah seorang tokoh hermeneutika asal Perancis.

Hermeneutika sebagai metode penafsiran kitab suci memiliki sejarah panjang yang mengalami perkembangan yang signifikan. Sahiron Syamsuddin membagi sejarah perkembangan hermeneutika menjadi tiga yaitu Hermeutika teks mitos, Hermeneutika teks Bibel, dan Hermeneutika

\footnotetext{
${ }^{13}$ Muzairi, Hermeneutika dalam Pemikiran Islam, hlm. 55.

14 Muzairi, Hermeneutika dalam Pemikiran Islam, hlm. 55-56.

${ }^{15}$ Muzairi, Hermeneutika dalam Pemikiran Islam, hlm. 56.
} 
umum. ${ }^{16}$ Sejarah hermeneutika tidak bisa terlepas dari sejarah penafsiran Bibel, karena itu Joseph W. Goering membagi periodesasi penafsiran Bibel di kalangan umat Kristiani menjadi empat; pertama, masa patristik (patristic age, abad 1-6 M), kedua, masa pertengahan tengah (central middle age, 7-11 M), ketiga, masa skolastik (skolastik age, abad 11-15 M), keempat, masa modern (modern age, abad 18 sampai sekarang). ${ }^{17}$ Sementara itu, Anthony C. Thiselton membaginya ke dalam tiga periode atau fase yaitu fase pramodern, modern, dan fase post-modern. ${ }^{18}$ Pembagian periodesasi ini juga diikuti oleh M. Nur Kholis Setiawan. ${ }^{19}$

Mengenai aliran dalam hermeneutika, paling tidak ada dua aliran besar yaitu objektivis dan subjektivis. Aliran objektivis masih mengakui makna asli atau otentik (original meaning) dari sebuah teks yang dikehendaki oleh pengarang (author). Aliran ini menekankan bahwa makna sebuah teks adalah makna yang diinginkan atau dimaksud oleh pemilik, penulis, atau pengarang teks itu sendiri. Peran pembaca (reader) dalam hal ini sangat kecil terhadap pemaknaan sebuah teks. Salah satu tokoh aliran ini adalah Emilio Betti (1890-1968). Adapun aliran subjektivis, ia lebih menekankan makna yang dimaksud oleh pembaca (reader) buka pengarang teks. Aliran ini tidak percaya terhadap makna otentik (original meaning), karena setiap penafsir sudah memiliki pra-pemahaman (pre-understanding) sebelum berhadapan dengan teks. Salah satu tokoh aliran ini adalah Hans-George Gadamer (1900-2002). Gadamer mengatakan sebagaimana dikutip oleh Nur Kholis Setiawan:

${ }^{16}$ Sahiron Syamsuddin, Hermeneutika dan Pengembangan Ulumul Qur'an, hlm. 11.

17 Joseph W. Goering, Introduction to Medieval Christian Biblical Interpretation, dikutip dari Sahiron Syamsuddin, Hermeneutika dan Pengembangan Ulumul Qur'an, hlm. 12 (lihat footnote nomor 19).

18 Anthony C. Thiselton, New Horizons in Hermeneutics, dikutip dari Sahiron Syamsuddin, Hermeneutika dan Pengembangan Ulumul Qur'an, hlm. 13.

19 M, Nur Khalis Setiawan, Emilio Betti dan Hermeneutika Sebagai Auslengung, dalam Syafa'atun Almirzanah dan Sahiron Syamsuddin (ed), hlm. 3. 
Immer ist in Verstehen ein Vorverstandnis in Spiel, das seinerseits durch die bestimmende Tradition, in der Interpret steht, und durch die in ihr geformte Vorurteile gepragt ist (Dalam proses pemahaman, prapemahaman selalu memainkan peran; prapemahaman ini diwarnai oleh tradisi yang berpengaruh di mana seorang penafsir berada, dan juga diwarnai oleh prejudis-prejudis [Vorurteile, perkiraan awal] yang terbentuk di dalam tradisi tersebut). ${ }^{20}$

Dari penjelasan di atas maka pemikiran 'Umar bin Khațāāb sebenarnya bisa dikategorikan dalam pemikiran hermeneutika sebagaimana akan dilihat dalam tulisan ini. Sebelumnya akan dibahas tentang biografi 'Umar untuk mengetahui perannya dalam dunia Islam. Hal ini penting karena untuk mengetahui pemikiran seorang tokoh maka pembahasan tentang latar belakang kehidupan dan hal-hal terkait sangat penting dilakukan. Seseorang tidaklah hidup dalam ruang hampa budaya, demikian juga dengan ‘Umar.

\section{BIOGRAFI SINGKAT ‘UMAR BIN AL-KHATTTĀB}

Mengkaji pemikiran seorang tokoh, kajian tentang biografi atau setting historis kehidupannya sangat penting. Tujuannya adalah untuk mengetahui lata belakang keluarga, pendidikan, sosial, budaya, ekonomi, dan hal-hal terkait yang mempengaruhi pemikiran tokoh bersangkutan. Dengan mengetahui biografi tokoh, maka seseorang akan bisa mengkonstruksi pemikirannya. Dari segi ilmu sejarah, kajian tokoh bisa dikategori menjadi empat; tokoh klasik, abad pertengahan, modern, dan postmodern. Dalam kaitannya dengan tulisan ini, bisa dikategorikan kepada pemikiran tokoh klasik karena yang dikaji adalah seorang sahabat Nabi. Sahabat yang hidup pada masa-masa awal Islam biasa disebut dengan formative period (masa pembentukan/'așr al-takwìn).

${ }^{20}$ Hans-George Gadamer, Das Problem des Historischen Bewussteins, dikutip dari M. Nur Khalis Setiawan, Pemikiran Progressif dalam Kajian Al-Qur'an (Jakarta: Kencana, cet-I, 2008 M), hlm. 98. 


\section{Setting Historis Kehidupan ‘Umar Pra Islam}

Dalam kaitannya dengan biografi 'Umar, sudah banyak dibahas dalam kitab-kitab rijāl al-ḥadìs, terutama sekali tentang biografi sahabat. 'Umar lahir tiga belas tahun sebelum tahun Gajah, yang berarti bahwa ia lebih muda tiga belas tahun dari Nabi Muhammad. Tahun Gajah terjadi pada tahun $571 \mathrm{M}$, dimana tentara yang menggunakan gajah datang ingin menghancurkan Ka'bah. Namun usaha mereka sama sekali sia-sia karena dihancurkan oleh Allah melalui burung Ababil. ${ }^{21} \mathrm{Di}$ kalangan Sunni, ‘Umar termasuk dalam kategori khulafaur rasyidin yang empat setelah Abū Bakar (w. 13 H). Tidak diragukan lagi bahwa kredibelitas 'Umar sangat dipercaya oleh sahabat-sahabat lain pada masa itu. 'Umar termasuk sahabat yang istimewa dalam Islam karena dengan masuk Islam maka Nabi bisa berdakwah secara lebih terbuka. Dalam kaitannya dengan hadis Nabi, ia meriwayatkan sebanyak 537 buah. ${ }^{22}$ 'Abbās Maḥmūd al-'Aqqād (1889-1964) telah menulis buku khusus tentang 'Umar dengan judul 'Abqariyah 'Umar (Kairo: Dār Hilāl, t.th). ${ }^{23}$ Buku telah membahas aspek-aspek yang terkait dengan 'Umar, termasuk beberapa ijtihadnya.

${ }^{21}$ Dalam Al-Qur'an, peristiwa ini diabadikan sehingga ada surat bernama Al-Fìl yang berarti gajah ([105], 1-5) sebagaimana firman Allah:

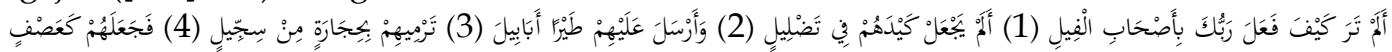

مَأْكُوٍ (5)

1.Apakah kamu tidak memperhatikan bagaimana Tuhanmu telah bertindak terhadap tentara bergajah? 2. Bukankah Dia telah menjadikan tipu daya mereka (untuk menghancurkan Ka'bah) itu sia-sia? 3. dan Dia mengirimkan kapada mereka burung yang berbondong-bondong, 4. yang melempari mereka dengan batu (berasal) dari tanah yang terbakar, 5. lalu Dia menjadikan mereka seperti daun-daun yang dimakan (ulat).

${ }^{22}$ Syamsuddīn Abū 'Abdillāh Muhạmmad bin Aḥmad bin 'Uṡmān bin Qaimāz al-Żahabī, Tajrìd Asmā' Al-Ṣahābah, juz-I, (Beirut: Dār Al-Ma'rifah, t.th), hlm. 397.

${ }^{23}$ Dalam bahasa Indonesia buku ini telah diterjemahkan oleh Bustami A. Gani dan Zainal Abidin Ahmad dengan judul Kecemerlangan Khalifah Umar bin Khathab (Jakarta: Bulan Bintang, cet-I, 1978). Dalam edisi yang diterjemahkan oleh Abdulkadir Mahdamy berjudul Keagungan Umar bin Khathab (Solo: CV Pustaka Mantiq, cet-I, 1992, cet-III, 1993). 
Nama lengkapnya adalah 'Umar bin al-Khaț̣āb bin Nufail bin 'Abd al-'Uzzā bin Riyāḥ bin 'Abdullāh bin Qarṭ bin Rizāḥ bin 'Adī bin Ka'ab bin Lu'aiy bin Gālib al-Qurasyī al-'Adawī, dengan kuniah Abū Ḥafṣ. ${ }^{24}$ Sedangkan ibunya bernama Hantamah binti Hāsyim bin Mugīrah bin 'Abdullāh bin 'Umar bin Makhzūm, sebagian pendapat mengatakan ibunya bernama Hantamah binti Hisyām. Namun pendapat pertama yang lebih kuat. 'Umar lahir empat tahun sebelum Perang Fijar, sebagian pendapat mengatakan 13 tahun setelah terjadi penyerangan “Tentara Bergajah”. 'Umar termasuk kalangan anggota Quraisy yang sangat dihormati dan disegani.

Dalam kaitannya dengan periwayatan hadis, 'Umar meriwayatkan dari Nabi sendiri, Abū Bakar, dan Ubay bin Ka'ab. Sedangkan orangorang yang meriwayatkan darinya antara lain 'Abdullāh, 'Āṣim, Ḥafṣah, 'Uṡmān, 'Alī, Sa'ad bin Abū Waqqāṣ, Ṭalhah bin 'Ubaidillāh, 'Abd al-Raḥmān bin Auf, Ibn Mas'ūd, Syaibah bin Usman al-Ḥajabī, Asy'aś bin Qays, Jarīr bin Abdullah al-Bajalī, Ḥużaifah bin Yamān, 'Amru bin al-'Āṣṣ, Mu'āwiyah, 'Adī bin Ḥātim, Hamzah bin 'Amr AlAslamī, Zaid bin Ṡābit, Sufyān bin 'Abdullāh al-Śaqafī, 'Abdullāh bin Unais al-Juhannī, 'Abdullāh bin 'Amr bin Al-'Āṣṣ, Abdullah bin 'Abbās, bin Abdullah bin Zubair, 'Uqbah bin 'Āmir Al-Juhannī, Faḍālah bin 'Ubadi, Ka'ab bin 'Ujrah, Miswar bin Makhramah, Nāfi' bin 'Abdul Ḥāris̀, Abu Umāmah al-Bāhilī, Abū Qatādah al-Anșārī, Abu Hurairah, Abu Mūsā al-Asy'arī, 'Āisyah, Anas bin Mālik, Jābir bin 'Abdullāh alAnșārī, Barrā' bin 'Āzib, Nu' mān bin Basȳ̄r.

24 Syamsuddīn Abū 'Abdillāh Muhammad bin Ahmad bin 'Uṡmān bin Qīmāz al-Żahabī, Al-Kāsyif Fì Ma'rifah Man Lahu Riwāyah Fì al-Kutub Al-Sittah, dita'līq dan ditakhrīj oeh Muḥammad 'Awwāmah dan Aḥmad Muḥammad Namir al-Khațīb, juz-II (Jeddah: Mu'assasah 'Ulūm al-Qur'ān, cet-I, 1413 H/1992 M), hlm. 59. Syihābuddīn Abū al-Faḍal Aḥmad bin 'Alī bin Muhammad Al-'Asqalānī Al-Mișrī, Tahżīb al-Tahż̄ib, dengan pentaḥqīq Ibrāhīm al-Zaibaq dan 'Ādil Mursyid, jilid-IV (Beirut: Mu'assasah al-Risālah), hlm. 221-222. Penulis yang sama, Taqrïb al-Tahżỉb, ditaḥīiq dan dita'līq oleh Abū al-Asybāl Ṣagīr Aḥmad Syāgif al-Bākistānī (Riyāụ: Dār al-'Āṣimah li al-Nasyr wa al-Tauzī', t.th), hlm 717. 
Selain dari kalangan sahabat, beberapa tabi'in pernah bertemu' Umar dan meriwayatkan darinya. Di antara mereka adalah 'Amr bin Maimūn al-Audī, Aslam bin Zaid (mantan budak 'Umar), Sa'īd bin Musayyib, Suwaid bin Gaflah, Syuraih al-Qāḍī, 'Ābis bin Rabī'ah 'Abdur Raḥmān bin 'Abdul Qārī, 'Ubaid bin 'Umair al-Lais̀ì, 'Alqamah bin Waqqāṣ al-Lais̀ī, Abu Maisarah 'Amru bin Syuraḥbīl, Qays bin Abu Ḥāzim, Ma'dān bin Abu Ṭalḥah al-Ya'murī, Abū Tamīm al-Jaisyānī, Abu 'Ubaid (mantan budak Ibn Azhar), Abu al-Ajfā' al-Sulamī, Abu ‘Uṡmān al-Nahdī, dan lain-lain. Dalam sejarah pemikiran Islam, 'Umar memang orang yang memiliki pengaruh besar terhadap ilmu-ilmu keislaman, seperti kajian Al-Qur'an, hadis, fiqih, dan sebagainya.

\section{Setting Historis Kehidupan Pasca Islam}

Setelah 'Umar masuk Islam, Nabi Muhammad bisa melakukan dakwah secara terang-terangan karena pengaruh 'Umar sangat besar di kalangan suku Quraisy. Beberapa hadis menyebutkan bahwa Nabi Muhammad sering memuji 'Umar karena ijtihadnya yang kadangkadang sesuai dengan Al-Qur'an. Dalam kajian ilmu asbāb al-nuzūl, ungkapan 'Umar bin Khaț̣āb (w. $23 \mathrm{H}$ ) sangat jelas sebagaimana diriwayatkan oleh al-Bukhārī (w. 256 H) dalam kitab Ṣaḥịh-nya:

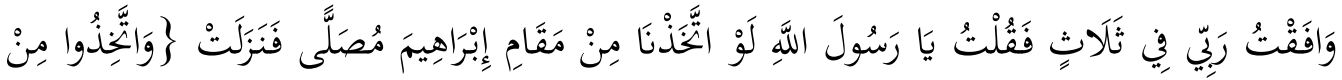

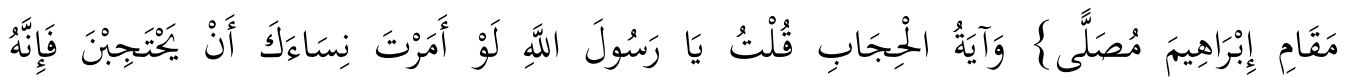

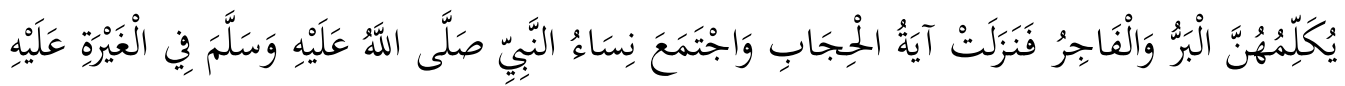

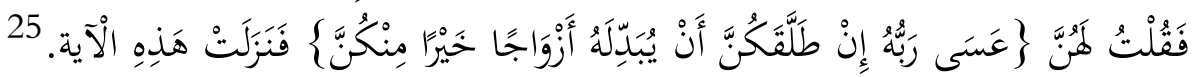

${ }^{25}$ Abū 'Abdillah Muḥammad bin Ismā’îl bin Ibrāhīm bin al-Mugīrah bin Bardiżbah al-Ju'fī al-Bukhārī, al-Jāmi' al-Șahịh' Kitāb al-Ṣalāh, Bāb mā jā'a fi al-Qiblah wa mallam yaral iādata alā man sahā, fașallā ilā gairil qiblah, no. 402. Edisi baru dalam satu jilid oleh Ḥassān 'Abdul Mannān (Libanon: Bait al-Afkār al-Daulīyah, cet-I, 2008), hlm. 89. Nama lengkap kitab ini adalah al-Ṣahīh al-Musnad min Hadīs Rasūililāh Ṣallallähu 'Alaihi wa Sallam wa Sunanihi wa Ayyāmihi atau al-Jämi' al-Musnad al-Șahīh al-Mukhtashar min Umüri Rasūlilläh Șallallähu 'alaihi wa Sallam wa Sunanihi wa Ayyāmihi. 
'Umar bin al-Khațāa berkata, Aku memiliki pemikiran yang aku ingin dikabulkan oleh Rabbku dalam tiga persoalan. Maka aku sampaikan kepada Rasulullah saw, 'Wahai Rasulullah, seandainya Maqam Ibrahim kita jadikan sebagai tempat shalat? Lalu turunlah ayat: '(Dan jadikanlah sebagian maqam Ibrahim sebagai tempat shalat). ${ }^{26}$ Yang kedua tentang hijab. Aku lalu berkata, 'Wahai Rasulullah, seandainya Tuan perintahkan isteri-isteri Tuan untuk berhijab karena yang berkomunikasi dengan mereka ada orang yang salih dan juga ada yang fajir (suka bermaksiat).' Maka turunlah ayat hijab. Dan yang ketiga, saat isteri-isteri beliau cemburu kepada beliau (sehingga banyak yang membangkang), aku katakan kepada mereka, 'Semoga bila beliau menceraikan kalian, Rabbnya akan menggantinya dengan isteri-isteri yang lebih baik dari kalian.' Maka turunlah ayat tentang masalah ini."27

Dari penjelasan di atas tentang pengertian $a s b \bar{a} b$ al-nuzūl, ada dua hal yang bisa dikemukanan. Pertama, ada ayat-ayat Al-Qur'an yang tidak memiliki sebab turunnya. Kedua, ada ayat-ayat Al-Qur'an yang turun dengan sebab (kejadian, peristiwa atau pertanyaan sahabat kepada Nabi saw) ${ }^{28}$ sebagaimana ungkapan ‘Umar di atas.

\section{Menjadi Khalifah}

Menurut Aqidah Ahlus Sunnah Wal Jamaah, penetapan khalifah setelah wafatnya Rasulullah saw pada tahun 11 H/632 M, merupakan

${ }^{26}$ Redaksi ayat itu adalah Q.S. Al-Baqarah [2]: 125:

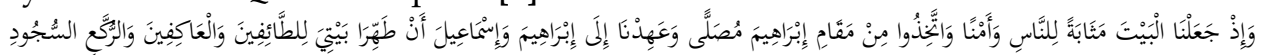

"Dan (ingatlah), ketika Kami menjadikan rumah itu (Baitullah) tempat berkumpul bagi manusia dan tempat yang aman. dan Jadikanlah sebahagian maqam Ibrahim tempat shalat. dan telah Kami perintahkan kepada Ibrahim dan Ismail: "Bersihkanlah rumah-Ku untuk orang-orang yang thawaf, yang i'tikaf, yang ruku' dan yang sujud".

27 Redaksi ayat itu terdapat dalam surat al-Tahrīm [66]: 5:

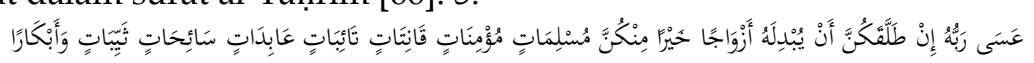

Jika Nabi menceraikan kamu, boleh Jadi Tuhannya akan memberi ganti kepadanya dengan isteri yang lebih baik daripada kamu, yang patuh, yang beriman, yang taat, yang bertaubat, yang mengerjakan ibadat, yang berpuasa, yang janda dan yang perawan.

${ }_{28}$ Jalāluddīn Abū al-Faḍal 'Abdur Raḥmān bin Abū Bakar al-Suyūțī, Al-Itqān fì 'Ulūm alQur'ān, ditashih dan ditakhrij oleh Muhammad Sālim Hāsyim (Beirut: Dār al-Kutub al-'Ilmīyah, cet-IV, 1433 H/2012 M), hlm. 48. Khālid bin 'Uṡmān al-Sabt, Qawā'id al-Tafsìr: Jam'an wa Dirāsah, j-I (Dār Ibn ‘Affān, 1421 H), hlm. 53. Nūruddīn ‘Itr, 'Ulūm al-Qur'ān al-Karìm, hlm. 46. 
bagian yang penting dalam Islam. Tidak hanya penetapan nama-nama khalifah yang empat, urutan-urutannya pun harus disesuaikan berdasarkan masa jabatan pemerintahan masing-masing. Dalam tradisi Islam, khalifah merupakan istilah yang digunakan bagi seorang pemimpim pemerintahan atau kepada negara. Kata khalifah sendiri sudah ada sejak masa Nabi Muhammad masih hidup karena Al-Qur'an juga menggunakan kata tersebut kepada Nabi Adam. Sejarah mencatat bahwa khalifah pertama menurut kelompok Sunni atau Ahlus Sunnah Wal Jama'ah adalah Abū Bakar, kemudian ia menunjuk ‘Umar sebagai penggantinya. Pada masa pemerintahan 'Umar, banyak negeri-negeri dikuasai oleh umat Islam.

Di antara jasa besar 'Umar bin Khațțāb pada masa pemerintahannya adalah pembagian negara Islam menjadi beberapa wilayah, yaitu Makkah, Madinah, Thaif, Yaman, Bahrain, Mesir, Syam/Syiria, Irak-Persia, Basrah, Kufah, Mada'in, dan Azerbaijan. ${ }^{29}$ Kota-kota inilah yang dikemudian hari banyak melahirkan berbagai macam ilmuan, baik dalam bidang tafsir, hadis, fikih, ushul fikih, filsafat, ilmu kalam, tasawuf, dan lain sebagainya. 'Umar dikenal sebagai khalifah yang adil karena kebijakan-kebijakannya yang menguntungkan kaum lemah atau kelas bawah. Meskipun demikian, ada beberapa kalangan yang tidak setuju dengan sikap dan kebijakan 'Umar. Sebenarnya kelompok pemberontak sudah mulai muncul pada masa pemerintahannya, namun banyak yang tidak bisa dideteksi.

Berbeda halnya dengan Sunni, kalangan Syi'ah berusaha mencari kesalahan-kesalahan 'Umar dari berbagai macam literatur. Dari berbagai macam literatur yang dianalisis, Muhammad Tijani

${ }^{29}$ Untuk kajian lebih mendalam, lihat Muhammad Ash-Shalabi, The Great Leader of Umar bin Al-Khathab, trj. Khoirul Amru Harahap dan Akhmad Faozan (Jakarta: Pustaka Al-Kautsar, cet-I, 2008). 
mengemukakan beberapa kesalahan fatal ijtihad 'Umar bin Khațtāb. Di antaranya adalah; (1). Umar berani menghina dan menyakiti hati Fathimah dengan mengancam akan membunuh dan membakar rumahnya jika ia tidak mau berbait pada Abu Bakar. (2). Umar melarang penulisan hadis dan membakar hadis-hadis Nabi Muhammad (3). Umar menolak bergabung dengan pasukan Usāmah bin Zaid yang diperintahkan oleh Rasulullah saw. (4). Umar melarang dan mencegah memberikan bagian zakat kepada para muallaf, (5). Mengharamkan mut'ah haji dan mut'ah wanita sebagaimana yang dihalalkan oleh Rasulullah saw. (6). Tidak melaksanakan hukuman rajam kepada Khālid bin Al-Walid yang terbukti berzina dengan isteri sahabat yang lain. Hal ini dilakukan setelah Khālid membunuh sahabat tersebut ketika memimpin perang terhadap kaum yang tidak mau membayar zakat kepada khalifah. (7). Membuat kreasi baru dalam azan yang tidak pernah diajarkan oleh Rasulullah. (8). Membolehkan orang untuk meninggalkan shalat pada waktu tidak ada air. (9). Membolehkan shalat sunnah berjamaah dan menamakannya tarawih, pada pada masa Nabi tidak ada. (10). Menciptakan kelas dalam masyarakat, sesuatu yang justeru Nabi menghapusnya. (11). Membentuk dewan syura untuk memilih penggantinya dan menunjuk 'Abdurraḥmān bin 'Auf sebagai ketuanya. ${ }^{30}$

Apa yang dikemukakan oleh Muhammad Tijani perlu dianalisis secara mendalam karena tidak semua tuduhan tersebut benar. Meskipun benar umpamanya, maka tidak serta merta menghakimi atau menjustifikasi sebagai ijtihad 'Umar yang salah. Salah satu hal yang

${ }^{30}$ Muhammad Tijani, Al Syiah Hum Ahlu Sunnah: Studi Kritis Informatif Polemik Antara Klaim dan Fakta, trj. S. Ahmad (Jakarta: El Faraj Publishing, cet-I, 2007), hlm. 185-186. Hal yang senada juga diungkapkan oleh Muhammad Babul Ulum, Kesesatan Sunni-Syi'ah: Respon Atas Polemik di Harian Republika (Depok: Aksara Pustaka, cet-I, 1434 H/2013 M), Penulis yang sama Polemik Sunni-Syiah (Bandung: Penerbit Jembar, cet-I, 2014). 
menjadi polemik Sunni-Syiah tentang tentang keadilan sahabat ('adālah al-ṣahābah) yang sampai sekarang belum terselesaikan. Hal yang sudah dimaklumi bahwa Syi'ah memang lebih mengutamakan 'Ali daripada sahabat-sahabat lainnya. Bahkan menganggap mereka telah merampas hak Ahlul Bait, ${ }^{31}$ secara khusus kekhalifahan 'Ali bin Abū Ṭālib (w. 40 $\mathrm{H})$.

\section{Wafatnya 'Umar}

Setelah memimpin selama kurang lebih 10 tahun, akhirnya 'Umar meninggal dunia karena dibunuh oleh Abū Lu'lu'ah Fairūz al-Majūsī tahun 23 Hijriah. ${ }^{32}$ Peristiwa ini terjadi pada hari Rabu bulan Żulhijjah tahun 23 Hijriah. Abū Lu'lu’ah Fairūz Al-Majūsī menikam ‘Umar ketika beliau sedang menjadi Imam shalat Subuh memakai pisau bermata dua dengan tiga tikaman atau enam tikaman (sebagian pendapat). Salah satu tikaman mengenai bagian bawah pusar 'Umar, yang membuat makanan keluar dari bawah pusar tersebut. 'Umar meminta 'Abdur Raḥmān bin 'Auf sebagai pengganti Imam shalatnya. Abū Lu'lu'ah menikam secara membabi buta, sehingga tigabelas sahabat terkena sabetan pisaunya, enam orang di antaranya meninggal dunia. Akhirnya Abū Lu'lu'ah membunuh dirinya sendiri, tentu ini merupakan sikap pengecut. Sebelum meninggal dunia, 'Umar berpesan kepada enam orang tokoh sahabat untuk memilih penggantinya. Enam orang sahabat itu adalah 'Uṡmān bin 'Affān, 'Alī bin Abū Ṭālib, Ṭalhahah, Zubair bin

${ }^{31}$ Kajian analisis tentang Ahlul Bait telah dikaji oleh Alwi Husein, Diskursus Ahl al-Bayt Nabi saw Dalam Hadis (Jakarta: Zahra, cet-I, 1436 H/2015 M). Buku ini merupakan tesis penulisnya di Pascasarjana UIN Syarif Hidayatullah Jakarta tahun 2015.

32 Lihat penjelasan lengkapnya dalam 'Imāduddīn Abū al-Fidā' Ismā'îl bin ‘Umar bin Kaṡīr al-Qurasyī al-Dimasyqī, al-Bidāyah wa al-Nihāyah, ditaḥqīq oleh 'Abdullāh bin 'Abdul Muḥsin alTurkī, jilid-X (Madinah: Dār al-Buhūì wa al-Dirāsāt al-'Arabīyah wa al-Islāmīyah, cet-I, 1418 H/1998 M), hlm. 189-190. Lihat juga Haidar Barong, Umar bin Khattab Dalam Perbincangan: Penasfiran Baru (Jakarta: Yayasan Cipta Persada Indonesia, cet-I, 1994), hlm. 317-322. 


\begin{abstract}
'Awwām, 'Abdur Raḥmān bin 'Auf, dan Sa'ad bin Abū Waqqāṣ..33
Setelah keenam sahabat besar tersebut musyawarah untuk memilih pemimpin, akhirnya mereka sepakat memilih 'Uṡmān bin 'Affān sebagai khalifah ketiga. ${ }^{34}$ Pada bulan Muharram tahun 23 Hijriah, ‘Usmān dilantik. Sebenarnya 'Umar telah menjalankan sistem musyawarah yang diperintahkan oleh Al-Qur'an.
\end{abstract}

\title{
D. HERMENEUTIKA `UMAR BIN AL-KHATTTĀB
}

Sebagaimana disebutkan di atas bahwa hermeneutika dalam pengertian metode penafsiran atau pemahaman terhadap kitab suci, maka tradisi Islam sudah sejak dahulu memilikinya. Pemikir-pemikir Barat dan sarjana Islam umumnya memasukkan istilah tersebut ke dalam sejarah Islam klasik (classical Islam).

Sebagaimana telah dijelaskan di atas bahwa hermeneutika dalam pengertian metode memahami Al-Qur'an sebenarnya sudah ada dalam tradisi Islam. Hal ini sebagaimana akan dilihat dari pemahaman 'Umar terhadap beberapa ayat. Dalam sejarah Islam, terutama sejarah Al-Qur'an, 'Umar dikenal sebagai orang yang pertama memiliki ide untuk membukukan Al-Qur'an secara utuh pada masa khalifah Abū Bakar (w. 13 H/634 M). ${ }^{35}$ 'Umar tetap meneruskan praktik para Kaisar Bizantium yang mempertahankan sistem dīwān atau registarsi. Selain itu, 'Umar juga

33 Ibn Kasīir al-Dimasyqī, al-Bidāyah wa al-Nihāyah, jilid-X, hlm. 190. Sebenarnya ada satu sahabat lagi yang layak ditunjuk sebagai panitia pemilihan khalifah, yaitu Sa'īd bin Zaid bin 'Amru bin Nufail al-'Adawī. Tetapi 'Umar tidak menunjuknya supaya tidak terjadi fitnah di kemudian hari, karena mereka berdua dari suku yang sama.

34 Beberapa sarjana Muslim telah menulis tentang kiprah 'Uṡmān bin 'Affān dalam Islam, di antaranya Muhammad Riḍā, 'Uśmān bin 'Affān Ż̀̄ al-Nūraini Sāliś al-Khulafā' al-Rāsyidīn (Mesir: Maṭba'ah İsā al-Bābī al-Ḥalabī, cet-II, 1383 H/1964 M). 'Alī Muhammad al-Ṣalabī, Sìrah Amìr al-Mu'mininn 'Uśmān Ibn 'Affān: Syakhṣiyatuhu wa 'Așruhu (Beirut: Dār al-Ma'rifah, cet-I, 2009), edisi bahasa Indonesia berjudul Biografi Utsman Bin Affan, trj. Masturi Irham dan Malik Supar (Jakarta: Pustaka Al-Kautsar, cet-I, 2013). Khalid Muhammad Khalid, 'Utsman ibn 'Affan: Khalifah Penjunjung Al-Qur'an, trj. Rashid Satari (Bandung: Mizan Media Utama, cet-I, 1436 $\mathrm{H} / 2014)$.

${ }^{35} \mathrm{Hal}$ ini sebagaimana terekam dalam beberapa kitab hadis dan sejarah Islam. 
membangun lembaga-lembaga dīwān, termasuk untuk pada tentara dan urusan finansial yang dikenal dengan kharaj, pajak pertahanan. Hal-hal ini yang menjadi pijakan ulama-ulama fikih belakangan. ${ }^{36}$

‘Umar mengadopsi budaya non-islam yang lain, yaitu 'usyur sebagai bentuk pajak tradisional yang ditujukan kepada para pedagang di daerahdaerah non-muslim. 'Usyur ini diterima 'Umar setelah mendapatkan informasi dari Abū Mūsā al-'Asy'arī tentang praktik pajak tersebut di daerah-daerah lain. 'Umar (w. $23 \mathrm{H}$ ) dan 'Alī (w. $40 \mathrm{H}$ ) menetapkan kerja sama dagang (muḍārabah) sebagai institusi yang legal. 'Uṡmān bin 'Affān (w. $35 \mathrm{H}$ ) berpartisipasi aktif dalam muḍārabah dengan 'Abdullāh bin 'Alī, sedangkan Ibn Mas'ūd dengan Zaid bin Khulaidah. 'Umar dikenal sebagai orang yang memiliki pergaulan luas dengan sahabat-sahabat yang lain, sehingga wajar jika pemikirannya sedikit atau banyak akan terpengaruh.

Selain itu, ‘Umar juga mengambil penafsiran sahabat terhadap ayat yang belum diketahui maksudnya. Dalam sebuah riwayat disebutkan bahwa 'Umar mengambil tafsir untuk memahami Al-Qur'an dari sahabat yang lebih yunior, yaitu Ibn 'Abbās (w. 68 H). Hal ini sebagaimana diceritakan sendiri oleh Ibn 'Abbās sebagai berikut:

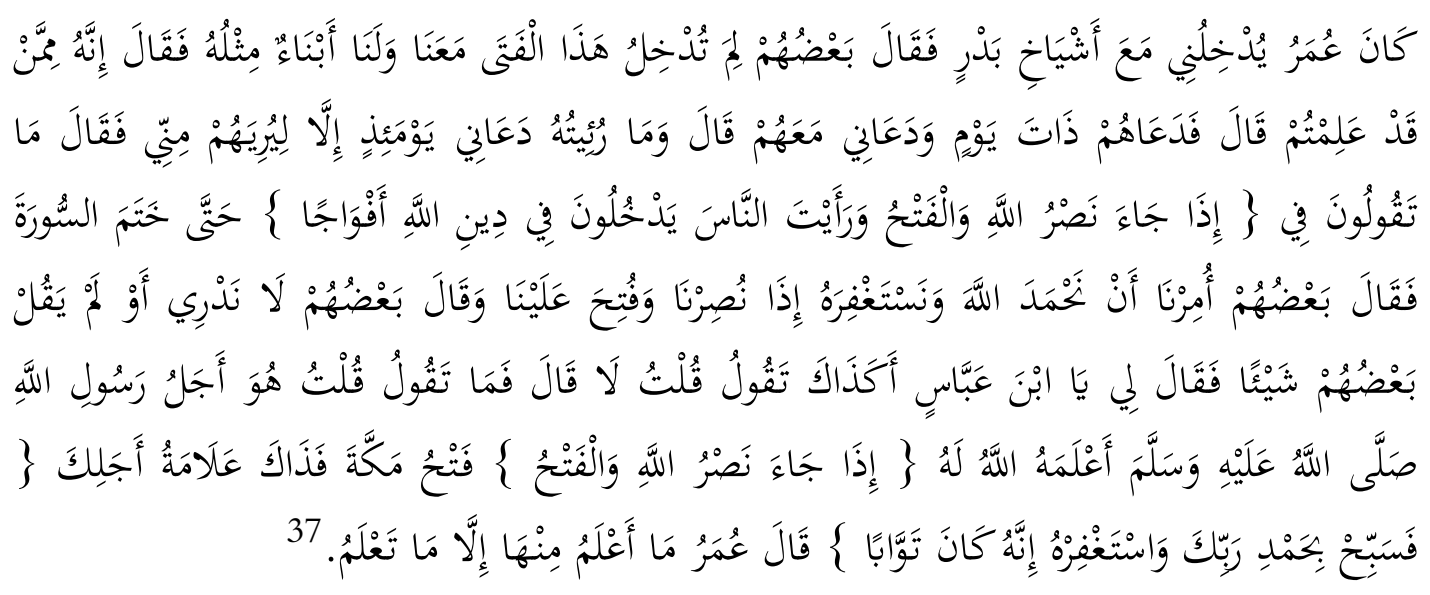

36 Dikutip dari Jamal Ma'mur, Rezim Gender di NU (Yogyakarta: Pustaka Pelajar, cet-I, 2015), hlm. 91. Saya sudah berusaha mencari atau melacak sumber yang lebih awal namun belum menemukan.

37 Șahịh al-Bukhārī, nomor. 3956. Sunan al-Tirmiżī, no. 3285. Musnad Ahmad, no. 2961. 
"Umar Pernah mengajakku dalam sebuah majlis orang dewasa, sehingga sebagian sahabat bertanya "Mengapa si anak kecil ini kau ikut sertakan, kami juga punya anak-anak kecil seperti dia?" Umar menjawab; "Kalian maklum, anak ini punya "kualitas" tersendiri." Kata Ibn 'Abbās, maka suatu hari Umar mengundang mereka dan mengajakku bersama mereka. Seingatku, Umar tidak mengajakku saat itu selain untuk memperlihatkan kepada mereka kualitas keilmuanku. Lantas Umar bertanya; "Bagaimana komentar atau pendapat kalian tentang ayat "Seandainya pertolongan Allah dan kemenangan datang (1) dan kau lihat manusia masuk agama Allah dengan berbondong-bondong (2) hingga ahkir surat (QS. Alfath 1-3). Sebagian sahabat berkomentar; "Tentang ayat ini, setahu kami, kita diperintahkan agar memuji Allah dan meminta ampunan kepada-Nya, tepatnya ketika kita diberi pertolongan dan diberi kemenangan. "Sebagian lagi berkomentar; "kalau kami nggak tahu. Atau bahkan tidak berkomentar sama sekali. Lantas 'Umar bertanya kepadaku; "Wahai Ibn 'Abbas, beginikah kamu berkomentar mengenai ayat tadi? "tidak" Jawabku."Lalu komentarmu? Tanya 'Umar. Ibn 'Abbās menjawab; "Surat tersebut adalah pertanda wafatnya Rasulullah saw sudah dekat, Allah memberitahunya dengan ayat ini: "Jika telah datang pertolongan Allah dan kemenangan', itu berarti penaklukan Makkah dan itulah tanda ajalmu (Muhammad), karenanya "Bertasbihlah dengan memuji Tuhanmu dan mohonlah ampunan, sesungguhnya Dia Maha Menerima taubat. Kata Umar, "Aku tidak tahu penafsiran ayat tersebut selain seperti yang kamu (Ibn 'Abbas) ketahui".

Penjelasan di atas menunjukkan bahwa pemikiran 'Umar telah dipengaruhi oleh pemikiran yang berasal dari luar diriya. Hal ini tidak mengherankan karena seseorang itu sangat dipengaruhi oleh lingkungan sekitar dan hasil interaksinya dengan orang lain. Karena itu tidak ada pemikiran yang lahir dari ruang kosong, sedikit atau banyak pasti pengaruh faktor dari luar memiliki dampak terhadap pemikiran, pemahaman atau penafsiran seseorang.

\section{E. KONSTRUKSI PEMIKIRAN `UMAR}

Dalam kaitannya dengan hermeneutika Islam, dibawah ini diberikan tiga contoh bagaimana pemahaman 'Umar yang progresif dan brilian dalam memahami Al-Qur'an. 'Umar membangun pola pikirnya dari realitas ke teks (min al-wāqi' ilā al-nașș) sekaligus dari teks ke realitas (min al- 
nașș ilā al-wāqi'). Ini merupakan salah satu ciri pemikir progresifkontekstualis yang dikembangkan oleh beberapa pemikir modern, seperti Ḥassān Ḥanafī, Nasr Hamid Abu Zaid, dan sebagainya.

\section{Ayat tentang pembagian zakat}

Dalam Al-Qur'an surat Al-Taubah [9] ayat 60 disebutkan bahwa ada delapan golongan yang berhak menerima zakat. Salah satunya adalah orang baru masuk Islam atau yang non muslim yang diharapkan akan masuk Islam. Dalam ilmu hukum Islam atau fikih disebut dengan muallafah quī̄buhum.

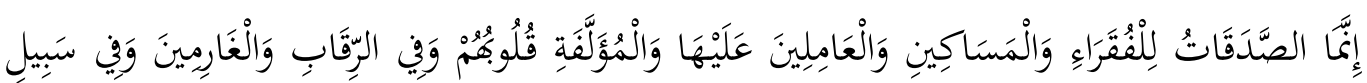

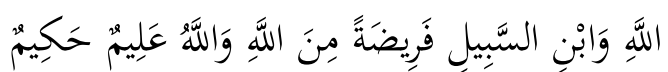

"Sesungguhnya zakat-zakat itu, hanyalah untuk orang-orang fakir, orangorang miskin, pengurus-pengurus zakat, Para mu'allaf yang dibujuk hatinya, untuk (memerdekakan) budak, orang-orang yang berhutang, untuk jalan Allah dan untuk mereka yuang sedang dalam perjalanan, sebagai suatu ketetapan yang diwajibkan Allah, dan Allah Maha mengetahui lagi Maha Bijaksana".

'Umar bin tidak membagikan zakat bagi mu'allafah qulūbuhum, yaitu orang-orang yang lemah imannya dan orang-orang yang belum masuk Islam tetapi diharapkan masuk Islam. Mereka ini diberi zakat ketika jumlah umat Islam masih sedikit dan masih dalam keadaan lemah, sehingga membutuhkan penambahan kuantitas dan menjaga diri dari kejahatan non-muslim. Meskipun demikian, 'Umar tidak memberi mu'allafah qulūbuhum karena jumlah umat Islam sudah banyak, menjadi kuat, dan negara dalam keadaan kuat dan berwibawa. Kondisi ini tentu telah membuat umat Islam menjadi kuat dan tidak perlu khawatir gangguan non-muslim. ${ }^{38}$

38 Riwayat semakna tentang hal ini dikutip oleh Haidar Barong, Umar bin Khathab Dalam Perbincangan (Penafsiran Baru) (Jakarta: Cipta Persada Indonesia, 


\section{Ayat tentang potong tangan}

Dalam Al-Qur'an disebutkan bahwa orang yang mencuri maka hukumannya adalah potong tangan. Namun ayat tersebut dibatasi oleh hadis yang menyebutkan bahwa tangan seorang pencuri dipotong apabila barang curian mencapai seperempat dinar. Inilah salah satu fungsi hadis, yaitu membatasi keumuman dan kemutlakan Al-Qur'an. Ayat tentang potong tangan berbunyi:

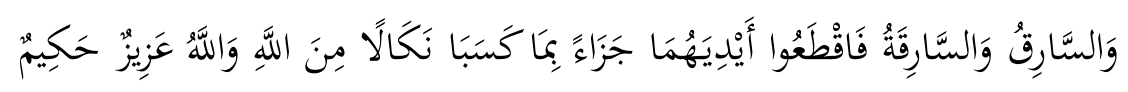

"Laki-laki yang mencuri dan perempuan yang mencuri, potonglah tangan keduanya (sebagai) pembalasan bagi apa yang mereka kerjakan dan sebagai siksaan dari Allah. dan Allah Maha Perkasa lagi Maha Bijaksana". (QS. Al-Mā'idah [5]: 38)

'Umar tidak menghukum potong tangan pencuri pada musim paceklik karena menjaga kehidupan harus didahulukan daripada menjaga nyawa. ${ }^{39}$ Kalau hal ini dikaitkan dengan maqūṣid al-syarīah, maka muncul kaidah hifzz al-nafs muqaddamun 'alā hifz al-māl. 'Umar telah memahami ayat tersebut secara kontekstual dengan melihat konteks sekitar atau situasi dan kondisi pada masa pewahyuan dan masa ‘Umar sendiri ketika terjadi peristiwa pencurian. Meskipun demikian, dalam konteks sekarang mungkin penegak hukum harus melihat segala kondisi yang ada ketika ada yang melakukan pencurian. Namun hal ini tentu disesuaikan dengan keadaan atau sitausi dan kondisi serta barang yang dicuri.

cet-I, 1994), hlm. 294. Lihat juga Faisal Ismail, Islam: Transformasi Sosial dan Kontinuitas Sejarah (Yogyakarta: Tiara Wacana, cet-I, 2001), hlm. 174. Jamal Ma'mur, Rezim Gender di NU (Yogyakarta: Pustaka Pelajar, cet-I, 2015), hlm. 91.

39 Dikutip dari Jamal Ma'mur, Rezim Gender di NU, hlm. 91. Faisal Ismail, Islam: Transformasi Sosial dan Kontinuitas Sejarah, hlm. 174. 


\section{Ayat tentang harta rampasan perang}

Pada masa Nabi Muhammad, setiap harta rampasan perang yang didapatkan maka akan dibagi-bagikan kepada pasukan perang. Pasukan kuda mendapat dau bagian sedangkan pejalan kaki mendapat satu bagian. Dalam Al-Qur'an surat Al-Anfāl ayat 1 disebutkan:

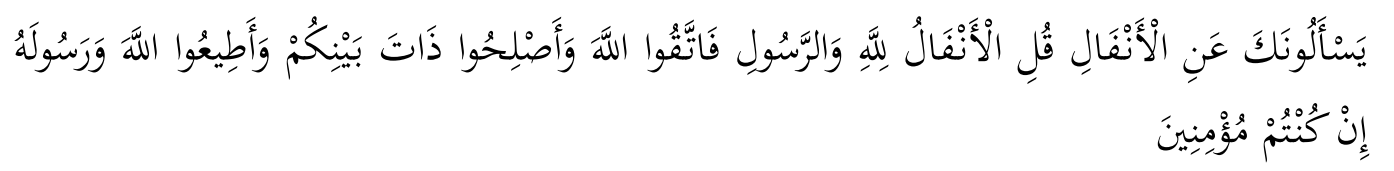

"Mereka menanyakan kepadamu tentang (pembagian) harta rampasan perang. Katakanlah: "Harta rampasan perang kepunyaan Allah dan Rasul, 40 oleh sebab itu bertakwalah kepada Allah dan perbaikilah perhubungan di antara sesamamu; dan taatlah kepada Allah dan RasulNya jika kamu adalah orang-orang yang beriman".

Sebagian ulama ada yang membedakan istilah ganinah dan anfäl, ada juga yang menyamakannya. Anfäl adalah apa yang diperoleh dalam peperangan sebelum mencapai kemenangan atau yang diperoleh dari musuh tanpa perang, sedangkan ganimah adalah harta yang diperoleh dari musuh setelah peperangan. Mayoritas ulama memang menyamakan kedua istilah tersebut, yaitu harta rampasan perang yang diperoleh setelah memerangi musuh agama yang kafir. Bisa juga maknanya adalah harta rampasan perang yang berlebih dari hak mereka. Menurut aturan, empat perlima dari harta rampasan perang dibagi kepada para pejuang, sedangkan seperlimanya dibagi oleh Rasul/panglima sesuai kebijaksanaannya. Pembagian ini bisa diberikan untuk orang tertentu maupun untuk kemaslahatan umum. ${ }^{41}$

Dalam memahami ayat di atas dan beberapa ayat yang terkait harta rampasan perang, 'Umar memiliki pemahaman atau penafsiran yang

40 Maksudnya: pembagian harta rampasan itu menurut ketentuan Allah dan Rasul-Nya.

${ }^{41}$ M. Quraish Shihab, Tafsir Al-Mishbah: Pesan, Kesan, dan Keserasian Al-Qur'an, Vol-4 (Jakarta: Lentera Hati), hlm. 453. Muhammad bin 'Umar Nawawī al-Jāwī, Marāh Labìd li Kasyf Ma'nā al-Qur'ān al-Majìd, ditahqīiq oleh Muḥammad Amīn al-Ḍannāwì, jilid-I, (Beirut: Dār al-Kutub al-'Ilmīyah, cet-V, 2011 M), hlm.hlm. 416. 
sangat inovatif dan progresif. Dalam artikel berjudul "Min Fiqh 'Umar fī al-Iqtiṣād wa al-Māl” karya Al-Bahī al-Khūlī dan artikel berjudul "Kaifa Ista'mala al-Ṣaḥābah 'Uqūlahum fī Fahm al-Qur'ān', telah dijelaskan tentang pemikiran brilian 'Umar bin al-Khțāāb dalam memahami AlQur'an. Isi kedua artikel tersebut kemudian dikutip oleh Nurcholish Madjid ${ }^{42}$ dalam bukunya, Islam Doktrin dan Peradaban. ${ }^{43}$ Berikut adalah kutipan penafsiran sekaligus dialog 'Umar dengan sahabat-sahabat lainnya.

Berita-berita tentang terbebasnya negeri Syam, Irak, dan Khusru (Persia) telah sampai kepada 'Umar, sementara beliau sedang berhadapan dengan masalah ekonomi. Harta benda musuh yang terdiri dari emas, perak, kuda, dan ternak telah menjadi harta rampasan perang (ganimah) di tangan bala tentara kaum muslimin. Tidak hanya itu, tanahtanah pertanian juga telah dikuasai oleh Islam. 'Umar telah mengambil seperlima harta tersebut, dan empat perlima dibagikan kepada bala tentara yang ikut dalam pembebasan wilayah Syam, Irak, dan Khusru. Apa yang dilakukan 'Umar sesuai dengan firman Allah dalam Al-Qur’an surat $A l-A n f a ̄ l .{ }^{44}$ Namun ada satu harta yang tidak dibagi-bagikan oleh ‘Umar kepada tentara muslim, yaitu tanah-tanah yang telah dikuasai.

42 Nurcholish Madjid atau yang biasa dikenal dengan Cak Nur merupakan salah seorang intelektual Muslim Indonesia yang sangat berpengaruh pada tahun 1980-an dan 1990-an. Pemikiran-pemikirannya banyak ditulis oleh peneliti dan akademisi, terutama sekali di lingkungan akademik kampus. Ia lahir di desa Mojoanyar, kecamatan Bareng, Jombang Selatan, tanggal 17 Maret 1939, dan wafat pada hari Senin pukul 14.02 WIB, tanggal 25 Agustus 2005. Madjid dimakamkan di Taman Makam Pahlawan Kalibata Jakarta, 30 Agustus 2005, pukul 10.15 WIB, dengan upacara militer dipimpin oleh Ketua MPR-RI Dr. Hidayat Nur Wahid, MA. Lihat Marwan Saridjo, Cak Nur: di Antara Sarung dan Dasi \& Musdah Mulia Tetap Berjilbab (Jakarta: Pena Madani, cet-II, 2005).

43 Nurcholish Madjid, Islam Doktrin dan Peradaban: Sebuah Telaah Kritis tentang Masalah Keimanan, Kemanusiaan, dan Kemodernan (Jakarta: Paramadina, cet-IV, 2000), hlm. 390-406.

44 Lihat redaksi ayat tersebut sebagaimana telah dikutip pada bagian sebelumnya. 
Menurut 'Umar, tanah-tanah itu harus diambil alih oleh negara, tidak boleh dibagi-bagikan. Tanah-tanah tersebut tetap dipegang oleh pemilik-pemiliknya, tetapi mereka harus membayar pajak (kharāj). Hasil pajak kemudian dibagi-bagikan kepada seluruh orang muslim setelah disisihkan dari gaji tentara yang ditempatkan di pos-pos pertahanan dan negeri-negeri yang telah dibebaskan. Tetapi kabanyakan sahabat menolak pendapat 'Umar tersebut dengan alasan tanah-tanah tersebut merupakan karunia Allah yang telah diberikan kepada kaum muslimin. Mereka berpendapat bahwa tanah-tanah tersebut harus dibagi-bagikan kepada bala tentara yang telah membebaskan wilayah-wilayah yang bersangkutan.

Sa'ad bin Abū Waqqāṣ menulis surat surat kepada 'Umar yang berisi bahwa sahabat-sahabat yang bersamanya di Irak menginginkan supaya tanah-tanah pertanian yang telah dibebaskan segera dibagibagikan. Dalam menanggapi isi surat tersebut 'Umar mengatakan: Lalu bagaimana dengan orang-orang muslim yang datang kemudian sesudah itu, mereka akan mendapati tanah-tanah telah dibagi-bagikan, terwariskan dari orang-orang tua dan dikuasi hanya beberapa orang? Ini bukanlah pendapat yang benar. 'Abdurraḥmān bin 'Auf: lalu apa pendapat yang benar? Tanah-tanah itu merupakan karunia Allah kepada mereka sebagai rampasan. 'Umar: Memang benar seperti yang engkau katakan, tetapi aku tidak melihat begitu. Demi Tuhan, tiada lagi suatu negeri akan dibebaskan sesudahku melainkan mungkin akan menjadi beban atas orang-orang muslim. Jika tanah-tanah pertanian di Irak dan Syam dibagi-bagikan, maka dengan apa biaya pos-pos pertahanan dibayar, dan apa yang tersisa bagi generasi berikutnya, dan para janda di negeri ini dan di tempat lain dari penduduk Syam dan Irak? Orang banyak: Bagaimana mungkin sesuatu yang dikaruniakan Tuhan kepada kami sebagai harta rampasan dengan perantaraan pedang-pedang kami 
akan engkau serahkan kepada orang-orang yang belum ada dan belum bersaksi, serta kepada anak cucu mereka yang belum ada?

Mendengar jawaban tersebut, 'Umar menjadi bingung dan termangu sambil berkata: ini adalah suatu pendapat. Kemudian sahabatsahabat yang lain menyuruh 'Umar untuk bermusyawarah. Maka ‘Umar pun bermusyawarah dengan tokoh-tokoh Muhajirin dan terjadi dialog: 'Abdurraḥmān bin 'Auf: "Aku berpendapat supaya engkau membagibagikan kepada mereka hak-hak mereka"

'Alī bin Abū Ṭālib: “Tapi pendapat yang benar ialah pendapatmu wahai Amirul Mukminin"

Zubair bin 'Awwām: Tidak! Sebaiknya, apa yang dikaruniakan Tuhan kepada kita sebagai rampasan dengan pedang kita itu harus dibagibagi".

'Uṡmān bin 'Affān: "Pendapat yang benar adalah yang dikemukakan ‘Umar"

Bilāl: Tidak! Demi Tuhan, sebaiknya kita harus melaksanakan hukum Tuhan terhadap harta yang dikaruniakan sebagai rampasan kepada hamba-hamba-Nya yang beriman".

Ṭalhah: "Aku berpendapat bahwa yang benar adalah yang dikemukakan 'Umar”.

Al-Zubair: Kemana kalian, wahai kaum, hendak pergi dari kitab Allah?"

'Abdullāh bin 'Umar: “Teruskan wahai Amirul Mukminin dengan pendapatmu itu. Sebab aku harap bahwa di situ ada kebaikan bagi umat ini".

Bilāl (sambil berteriak dan marah): "Demi Allah, tidak berlaku di umat ini kecuali apa yang telah ditentukan oleh Kitab Allah dan Sunnah Rasulullah saw".

'Umar (dalam keadaan sesak dada dan sedih): “Oh Tuhan, lindungilah aku dari Bilāl dan kawan-kawannya". 
Perselisihan tentang tanah-tanah pertanian tersebut berlangsung selama tiga tiga, dan kegaduhanpun semakin memanas. 'Umar berpikir supaya masalah tersebut dimusyawarahkan dengan tokoh-tokoh kaum Anșār. Akhir beliau mengumpulkan lima dari suku Aws dan lima dari suku Khazraj. 'Umar berpidato didepan mereka, setelah membaca ḥamdalah dan pujian lainnya, ‘Umar berkata:

“Aku tidak bermaksud mengejutkan kalian kecuali hendaknya kalian bersamaku dalam amanat urusan kalian yang dibebankan kepadaku, sebab aku hanyalah salah seorang saja di antara kalian. Hari ini hendaknya kalian membuat keputusan dengan benar, siapa yang ingin berbeda pendapat dengan ku silahkan, dan siapa yang ingin setuju denganku silahkan juga. Aku tidak ingin kalian mengikuti begitu saja hal yang menjadi kecenderunganku ini. Di tangan kalian ada Kitab Allah yang menyatakan kebenaran...Demi Tuhan, kalau aku pernah menyatakan suatu perkara yang kuinginkan, aku tidak menginginkannya kecuali kebenaran".

Kaum Anșār: "Bicaralah, dan kami semua akan mendengarkan, wahai Amirul Mukminin"

'Umar: Kalian telah mendengar pembicaraan mereka, kelompok yang menuduhku berbuat zalim terkait hak-hak mereka. Aku benar-benar berlindung kepada Allah dari melakukan kezaliman. Jika aku telah berbuat zalim kepada mereka berkenaan dengan sesuatu yang menjadi milik mereka dan aku memberikannya kepada orang lain, maka benarbenar telah celakalah diriku. Tetapi aku melihat bahwa tidak ada lagi sesuatu (negeri) yang dibebaskan setelah negeri Khusru (Persia), dan Allah pun telah merampas untuk kita harta kekayaan dan tanah-tanah pertanian mereka. Maka aku bagikan semua kekayaan (yang berkembang) kepada mereka yang berhak, kemudian aku ambil seperlimanya, aku atur menurut aturan tertentu, dan aku 
bertanggungjawab atas pengaturan itu. Tetapi aku berpendapat untuk menguasai tanah-tanah pertanian dan aku kenakan pajak atas para penggarapnya, dan mereka berkewajiban membayar jizyah sebagai fay' untuk orang-orang muslim, untuk tentara yang berperang serta anak cucu mereka, dan untuk generasi yang akan datang kemudian. Tahukan kalian pos-pos pertahanan itu? Di sana harus ada orang-orang yang tinggal menetap. Tahukah kalian, negeri-negeri besar seperti Syam, Jazīrah (Lembah Mesopotamia), Kufah, Basrah dan Mesir? Semuanya itu harus dijaga oleh tentara dan disediakan perbekalan untuk mereka. Dari mana mereka mendapat perbekalan itu jika semua tanah pertanian telah habis dibagi-bagi?

Sahabat yang hadir: "Pendapat yang benar adalah pendapatmu. Alangkah baiknya apa yang kau katakan dan lihat itu. Jika pos-pos pertahanan dan kota-kota itu tidak diisi atau dijaga oleh personilpersonil, serta disediakan bagi mereka perbekalan, maka tentulah kaum kafir akan kembali ke kota-kota mereka".

Dari penjelasan di atas bisa diketahui bahwa 'Umar telah melakukan penafsiran yang jauh melampaui sahabat-sahabat lain. Dalam konteks sekarang ia bisa dikategorikan sebagai pemikir hermeneutika. Dialog-dialog yang terjadi antara 'Umar dengan sahabatsahabat lainnya bisa diistilah dengan dialog antara kelompok tekstualis dan kontekstualis atau kelompok konservatif dengan progresif liberal. Metode tafsir atau hermeneutika 'Umar sangat sesuai diterapkan pada masa sekarang dalam memahami teks-teks keagamaan (Al-Qur'an dan hadis).

Abdullah Saeed dalam bukunya Interpreting the Qur'an: Toward a Contemporary Approach membagi klasifikasi mufassir menjadi tiga kelompok ketika berhadapan dengan teks-teks al-Qur'an; Textualist, Semi-textualist dan Contextualist. Pembagian ini tergantung kemampuan 
mufassir dalam menafsirkan ayat Al-Qur'an. Apakah hanya bertumpu pada analisis kebahasaan saja (linguistic criteria) dalam menentukan makna teks atau melihat kontek sosio-historis al-Qur'an, lebih-lebih konteks kontemporer saat ini (This classification is based on the degree to which the interpreters [1]. Rely on just the linguistic criteria to determine the meaning of the text, and [2]. Take into account the socio-historical context of the Qur'an as well as the contemporary context on today).45 Jika kita menggunakan tipologi Saeed, maka 'Umar termasuk dalam kategori penafsir kontekstualis.

\section{F. SIMPULAN}

Dari penjelasan di atas bisa dikatakan bahwa hermeneutika sudah ada dalam tradisi penafsiran Al-Qur'an abad klasik sebagaimana terlihat dalam pemahaman 'Umar bin Khațtāb. Metode pemahaman atau pemikiran 'Umar bin Khaț̣āb bisa disejajarkan dengan pemikir-pemikir modern lainnya. Beberapa kalangan menganggap 'Umar telah melanggar Al-Qur'an dan hadis dalam ijtihadnya, namun jika diteliti maka anggapan itu tidak benar. Hanya kalangan konservatif-tekstualis-fundamentalis saja yang meyalahkan penafsiran atau pemahaman 'Umar. Ia telah melakukan ijtihad yang sudah melampaui zamannya, bahkan untuk konteks sekarang sudah sangat maju.

Meskipun hermeneutika sudah diterima dan diaplikasikan dalam memahami Al-Qur'an, beberapa kalangan tetap saja menolaknya. Ini menjadi tugas akademik yang cukup bagi kita untuk memahampkan mereka. Secara historis, hermeneutika memang bukan dari tradisi Islam, tetapi esensinya bisa dipakai oleh kalangan manapun. Sebagaiman telah dijelaskan oleh Richad E. Palmer, bahwa salah satu makna hermeneutika

45 Abdullah Saeed, Interpreting the Qur'an: Toward a Contemporary Approach (London and New York: Routledge, cet-I, 2006), hlm. 3. 
adalah metode penafsiran kitab suci. Kitab suci ini tentu umum, setiap agama memiliki kitab suci, karena itu mereka juga bisa menggunakan hermeneutika. Paling tidak tulisan ini telah membuktikan bahwa tradisi hermeneutika sudah ada sejak masa Nabi, kemudian berkembang pada masa sahabat. Hal ini sebagaimana dilakukan oleh 'Umar bin Khaț̣āb dalam memahami ayat-ayat Al-Qur'an secara kontekstual.

Al-Qur'an harus mampu menjawab tantangan zaman sehingga slogan șāliḥun likulli zamān wa makān benar-benar membumi dalam kehidupan manusia. Tentu ini merupakan tugas kita semua, terutama kalangan akademik kampus untuk mendalami kajian Al-Qur'an. Selain itu, metode dan pendekatan harus digali supaya up to date seiring dengan perubahan zaman. Semangat hermeneutika atau ijtihad tafsir 'Umar bin Khaț̣āb harus digalakkan supaya pemikiran kita menjadi luas, inklusif, kreatif, progresif, dan inovatif. 


\section{DAFTAR PUSTAKA}

'Aqqad, Abbas Mahmud, Kecemerlangan Khalifah Umar bin Khathab, trj. Bustami A. Gani dan Zainal Abidin Ahmad, Jakarta: Bulan Bintang, cet-I, 1978. Dalam edisi yang diterjemahkan oleh Abdulkadir Mahdamy berjudul Keagungan Umar bin Khathab, Solo: CV Pustaka Mantiq, cet-I, 1992, cet-III, 1993.

Barong, Haidar, Umar bin Khattab Dalam Perbincangan: Penasfiran Baru, Jakarta: Yayasan Cipta Persada Indonesia, cet-I, 1994.

Faiz, Fakhruddin, Hermeneutika Qur'ani: Antara Text, Konteks, dan Kontekstualisasi, Yogyakarta: Qalam, 2002.

Gadamer, Hans-George, Philosophical Hermeneutics, trj. David E. Lingue, Berkeley: The University of California Press, 1997. , Truth and Method, New York: Crosscorad Publishing, 1986.

Hidayat, Komaruddin, Menafsirkan Kehendak Tuhan, Jakarta: Teraju, cet-II, 2004

Husaini, Adian, Wajah Peradaban Barat: Dari Hegemoni Kristen ke Dominasi Sekular-Liberal, Jakarta: Gema Insani Press, cet-I, 1426 H/2005 M.

Ibn Kașīr 'Imāduddīn Abū Al-Fidā' Ismā'îl bin 'Umar bin Kas̀īr Al-Qurasyī AlDimasyqī, Al-Bidāyah Wa Al-Nihāyah, ditaḥqīq oleh 'Abdullāh bin 'Abdul Muḥsin al-Turkī, jilid-X, Madinah: Dār al-Buhūìs wa al-Dirāsāt al'Arabīyah wa al-Islāmīyah, cet-I, 1418 H/1998 M.

Madjid, Nurcholish, Islam Doktrin dan Peradaban: Sebuah Telaah Kritis tentang Masalah Keimanan, Kemanusiaan, dan Kemodernan, Jakarta: Paramadina, cetIV, 2000.

Maimun, Ach, “Resistensi terhadap Hermeneutika dalam Kajian Al-Qur'an di Indonesia: Pemetaan Varian dan Kepentingan" dalam Suhuf: Jurnal Kajian Al-Qur'an, Vol-8, No. 2. November 2015

Saeed, Abdullah, Interpreting the Qur'an: Toward a Contemporary Approach, London and New York: Routledge, cet-I, 2006.

Shalabi, Muhammad, The Great Leader of Umar bin Al-Khathab, trj. Khoirul Amru Harahap dan Akhmad Faozan, Jakarta: Pustaka Al-Kautsar, cet-I, 2008.

Shihab, M. Quraish, Tafsir Al-Mishbah: Pesan, Kesan, dan Keserasian Al-Qur'an, Vol-4 Jakarta: Lentera Hati, 2004. 
Syamsuddin, Sahiron, Hermeneutika dan Pengembangan Ulumul Qur'an, Yogyakarta: Pesantren Nawesea Press, cet-I, 2009 M.

Tijani, Muhammad, Al Syiah Hum Ahlu Sunnah: Studi Kritis Informatif Polemik Antara Klaim dan Fakta, trj. S. Ahmad, Jakarta: El Faraj Publishing, cet-I, 2007

Ulum, Muhammad Babul, Kesesatan Sunni-Syi'ah: Respon Atas Polemik di Harian Republika, Depok: Aksara Pustaka, cet-I, 1434 H/2013 M. Polemik Sunni-Syiah, Bandung: Penerbit Jembar, cet-I, 2014.

Umar, M. Nasaruddin Umar, "Menimbang Hermeneutika sebagai Manhaj Tafsir", dalam Jurnal Studi Al-Qur'an, Vol-I, No, 1, Januari, 2006.

Wibowo, Safrudin Edi, "Kontroversi Penerapan Hermeneutika Dalam Studi AlQur'an di Indonesia", Disertasi, Pascasarjana UIN Sunan Kalijaga Yogyakarta, 2017.

Wijaya, Aksin, “Hermeneutika Al-Qur'an: Memburu Pesan Manusiawi Dalam Al-Qur'an", dalam Ulumuna: Jurnal Studi Keislaman, Vol. XV, No. 2, 2011.

Żahabī, Syamsuddīn Abū 'Abdillāh Muhammad bin Aḥmad bin 'Uṡmān bin Qīmāz, Tajrīd Asmā' Al-Ṣahābah, juz-I, Beirut: Dār Al-Ma'rifah, t.th. 